\title{
Handmaidens to Translators versus Feminist Solidarity - Opposing Politics of Translation in the Galician Literary System
}

\author{
María Reimóndez \\ Independent Researcher, Spain
}

\section{Introduction}

Lori Chamberlain's article "Gender and the Metaphorics of Translation" originally published in 1988 first described translators in general as "handmaidens to authors", opening up interesting avenues for feminist translation. Chamberlain's work highlighted the need to rethink the predominant theoretical concepts underlying traditional translation theory at that time, an effort that also called for a better understanding of the histories of concrete women translators. This article, however, cannot be read in isolation, as a series of scholars coming from feminism, postcolonialism and other fields (see, for example, Tymoczko and Gentzler 2002, Robinson 1997, Cronin and Gentzler 2002) contributed to the dismantling of the traditional idea of translation as a secondary activity. Such theoretical endeavours finally led to recognition of translators as creators and, in the case of feminist and postcolonial theories, they also unveiled how silencing and making translators invisible responded to the needs of hegemonic value systems. As long as translation and translators are invisible, the hegemonies can continue creating spheres of power where some are allowed to speak while others cannot, in the Spivakian sense. ${ }^{1}$

However, situated studies in particular times and spaces, in languages other than English, and in non-Western countries, of Chamberlain's theories suggest that perhaps the neat equation woman-translator-subordination does not always work in the way she initially presented. Some studies theorize that in certain literary systems and in specific situations, the translator may have more power than the original author, the study by von Flotow (1997) of the translation of Simone de Beauvoir's Le deuxième sexe into English being a case in point. Likewise, postcolonial approaches to translation have enriched this debate in their efforts to review both the foundations of translation theory and actual translation practices from a perspective that analyzes the contributions of translation to colonization, and also its scope for subversion (see for example Robinson 1997). Several studies stemming from this theoretical framework have shown that the power equation tends to change whenever the translator is a hegemonic subject and the author a postcolonial one. Perhaps the most widely quoted example for the English language is Abdulla's 1999 study of the translation of the Rubáiyát of Omar Khayyám by FitzGerald (1999). Rosemary Arrojo and Harish Trivedi (141-161) has also shed some light on how sometimes western feminist translators can fall prey to colonial strategies when translating the female Other in her study of Hélène Cixous' translations of Clarice Lispector. These analyses have been expanded by those works focusing on language and hegemony such as those of Ives and Lacorte 2010, Macedo et al 2003 and my own (forthcoming). The Gramscian concept of hegemony as power created through consent helps understand how some languages

${ }^{1}$ Please see "Can the Subaltern Speak?" (Spivak 1988). 
and their speakers become central and others marginal in particular contexts. ${ }^{2}$ From this perspective, writers in non-hegemonic languages, in particular women writers, have expressed concerns regarding the translation strategies and power imbalances in translations into hegemonic languages. Such criticism is appropriately summarized by Tamil feminist writer Ambai (C.S. Lakshmi):

Turning a culture into footnotes is a power politics a writer has to constantly resist. When we were young and read French and Russian novels, even American ones at times, I don't think footnotes were provided. One did not understand certain references to Greek or other mythologies nor some references to certain kinds of food. One did not quite know how champagne tasted and for a long time pronounced it as champ-page-ne. [...] We had to receive it the way it came and raise ourselves to its level. But our literature is seen as something that is flowing upward and something that takes that kind of a direction has to suit itself to the needs of that upward path. (66)

This paper aims at updating and broadening the scope of these approaches with examples taken from the Galician literary system, which may prove interesting as Galician identity occupies a space at the intersection of non-hegemonic and hegemonic identities. For centuries, the Galician language was excluded from decision-making spheres, and was preserved almost exclusively by the rural and lower socio-economic groups; it was forbidden during Franco's dictatorship, and conservative governments at both State and regional levels have introduced measures ${ }^{3}$ that have further diminished the already meagre rights of Galician speakers. ${ }^{4}$ The outcome of this historical situation is appropriately described by Iglesias Álvarez in her description of the present negative attitudes towards the language, leading to high levels of diglossia in order to avoid discrimination in specific settings. Callón addressed the issue of discrimination in the labour market, and further examples of this secondary status of the Galician language include the fact that academics writing in Galician do not have their work recognized at the same level as scholars writing in hegemonic languages (English in this case), which also means that they do not obtain the same income for their work. Galician has also been cut in education, where the so-called Decreto do plurilingüismo [Multilingualism Decree] states that only $33 \%$ of subjects may be taught in Galician. ${ }^{5}$ The outcome of all these policies and of the complex historical events leading up to this situation can be seen in the most recent survey on

\footnotetext{
2 A case in point is the acceptance, without any further discussion, of English as the language of the academia, without considering how many producers of knowledge worldwide are excluded from academic discussions (see Macedo et al. 2003).

${ }^{3}$ See for example Law 2/2009, which eliminates the specific requirement for all public employees in Galicia to pass a Galician language test to access these jobs. What this means in practice is that Galician speakers may find themselves not being understood by the staff of the very institution that has the mandate to protect and guarantee their rights, according to Galicia's Autonomy Statute of 1981.

4 For a recent and detailed discussion of the situation of the Galician language in English please see O'Rourke 2014.

5 The remaining subjects are expected to be taught in Spanish and English, although in practice lack of qualified staff and especially lack of understanding of the English language by students tends to mean that those subjects are also taught in Spanish. Furthermore, this Decree has introduced for the first time the legal prohibition of teaching subjects such as Mathematics in Galician, usually under the pretext of those subjects being too important to be taught in Galician. The situation was further aggravated by the Spanish LOMCE (Organic Law for the Improvement of Quality in the Educational System), see an analysis of the implications in the article "La LOMCE relega las lenguas cooficiales a 'asignatura de especialidad"' (2012).
} 
Galician language use, ${ }^{6}$ where for the first time in our history, the number of respondents claiming to use Galician as their habitual language fell below $50 \%$ and $11 \%$ of the population also claimed for the first time that they never spoke Galician. These examples show how language hegemony is far from being an abstract political claim, but a matter that clearly determines the opportunities, wealth and rights of citizens.

Despite the situation that has just been described, if we analyze the position of Galicia in the world at large, other aspects indicate that Galician identity can also be hegemonic towards non-Western Others. To begin with, we are part of one of the traditional colonial states, Spain, and close allies of another, Portugal ${ }^{7}$. Even though Galicians were forbidden by the Castilian Crown to participate in the first exploits of colonization, they did take part in it later on, many times-and hence the relevance of Portugal for this discussion-as members of Portuguese colonial crews (see for example Dizon and Rodríguez 2011 for a discussion of the participation of Galicians in the colonization of the Philippines from Magellan's first colonial expedition onwards. Later, the large presence of Galician migrants in former colonial territories—so much so in fact, that the term gallego (Galician) has become synonym for Spaniard in most Spanishspeaking Latin American countries-has recently been critically reviewed in light of its impact, for example, on indigenous and Afro-American communities in Latin America (see for example Naranjo Orobio 1999 for Cuba). These aspects also need to be considered in view of other more contemporary forms of (neo)colonization such as the exploitation of women and children in developing countries for the production of consumer goods and the perpetuation of the colonial imaginary that actually supports such exploitation. While world top textile manufacturer Inditex may not identify as "Galician", but rather as "Spanish", the fact is still that its founder is Galician, its main offices are in Arteixo, Galicia, and the revenue generated from taxes to this company goes in part to the Galician treasury. One also has to mention the fact that Inditex's founder regularly donates to schools and charities in Galicia ${ }^{8}$, and that even in nationalist circles Inditex is considered an example of a successful business model (see for example Vázquez Padín 2012). If one looks at the reports by the Clean Clothes Campaign, however, Inditex is also one of the companies about which violations of rights of women in developing countries are regularly reported. Another aspect one cannot overlook is the contribution of Galician nationalist circles to tropes of colonization such as the exotization of the Other. Just to name a few examples, already at the beginning of the $20^{\text {th }}$ century, the Galician nationalist movement (see the discussion later) produced works that looked at the Orient in the ways criticized by Edward Said (1979), such as those of Galician nationalist Vicente Risco in, for example El Oriente contado con sencillez: The use of colonial tropes can be found in contemporary writers too; for example Manuel Rivas' poetry collection Mobicania (1986) presents a link between the situation of Native Americans and Galicians in a way that equals the very unequal circumstances of both groups. From a postcolonial perspective, Inma López Silva's novel Memoria das cidades sen

\footnotetext{
${ }^{6}$ See the full study at the Instituto Galego de Estatística's website and an analysis by Lombao (2014).

${ }^{7}$ Galician and Portuguese were the same language until the $14^{\text {th }}$ century. They are still quite close, and there are also close cultural links with Portuguese-language countries. Two indicators of colonial alliances and the way they affect the position of Galicians towards the colonized world are joint spaces for political decision-making such as the Euro Region Galicia-North of Portugal and the development aid policies focusing on former Spanish or Portuguese colonies as priority areas, as I have described at some length in Reimóndez 2014.

${ }^{8}$ See the list of projects of Amancio Ortegas' Foundation.
} 
luz (2008) and her essay Maternosofía (2014) are quite problematic in their animalized and sexualized representation of black women see (see Sánchez Aríns 2014). Galician-language media also plays a role in the continuation of the colonial imaginary ${ }^{9}$, while institutions related the field of development aid also follow suit (see Reimóndez 2014).

All these aspects are relevant from the point of view of literary translation as they lay the foundations for the types of relationships that different actors in the Galician literary system may try to establish with other cultures through translation. Galicia seems to be an interesting crossroads in the sense Hooper and Puga explain: "If the twenty-first century is to be characterized, as Manuel Castells has argued, by the conflicting trends of globalization and identity, then Galicia provides the ideal location for exploration of the resulting tension" (2011: 1). The theoretical ${ }^{10}$ centrality of translation in the Galician-language literary system may be another relevant element I will discuss later in this article, in particular aspects related to gender and race affecting the role and power position that translators themselves occupy.

\section{The Construction of the "Powerful White Male Translator"}

In order to understand the specific development of the power constellation currently at work in the Galician literary system, one has to first understand how this system developed and its close links to ideas of a Galician nation. Galician nationalism, at least in its more primitive forms, developed during the $19^{\text {th }}$ century (see, for example, Fernández Prieto 2011), triggered by the idea of having a language and a literature of our own (see Figueroa 2011).

Translation was, in this context, an important tool that took on new guises as the political situation developed. ${ }^{11}$ Noia Campos 1995, in her history of Galician translation in European culture, singles out the Nós Generation and the Irmandades da Fala [Language Brotherhood] as the first movements since the Middle Ages to understand the importance of translation for the development of a Galician political identity. These two cultural and literary movements that flourished during the first decades of the $20^{\text {th }}$ century until the Spanish Civil War were grounded on a need to link Galicia to other (mainly European) nations and translation was, therefore, a key part of their efforts. After the violence of the Civil War and the ensuing dictatorship, Galician was granted the status of a co-official language in the Comunidade Autónoma de Galicia [Autonomous Community of Galicia], and the Lei de Normalización Lingüistica [Language Normalization Act] was passed in 1983. The term normalización was used from that moment onwards to express the idea that the Galician language had to be fostered at all levels in society, something that had an important effect on translation, as Noia Campos (1995: 53) once again highlights for the first decades after the Law was passed. Luna Alonso further clarifies this idea

\footnotetext{
9 See for example Arturo Lezcano’s feature "Vudú: o espírito dun pobo" in cultural magazine Luzes.

${ }^{10}$ I speak of "theoretical centrality" because translation has always been discussed as a very important pillar of the literary system, as we shall see later, while translations are hardly ever reviewed or discussed and ultimately not bought by a large share of readers. Maybe a key aspect to be considered here is the, in my opinion excessive, influence of Even Zohar's "Polysystem's Theory" (1996) on Galician translation scholars, especially during the 1990 s and first decade of the 2000s. A systematic review of the articles published in the Galician-language translation journal Viceversa attests to this fact.

${ }^{11}$ See González Millán 1995 for a detailed discussion of the general sociocultural considerations of translation in Galicia.
} 
of translation as being key to normalizacion:

Cómpre ter en conta que a tradución é un dos piares básicos na normalización do uso da lingua en todas as súas facetas e ámbitos [...] de aí que, máis alá das consideracións puramente económicas ou comerciais, sexa preciso un foment comprometido e decidido da tradución por parte das administracións e un apoio do sector da edición privada. ("Análise" 104) ${ }^{12}$

This idea of translation as key for normalización paved the way for a recurring discussion on the need to translate "the Classics". Luna Alonzo further explains the context of this development:

O sistema literario galego precisaba, e aínda precisa, do apoio dos clásicos e dunha temática moi concreta, tanto en produción propia como en tradución, para manter un sistema literario feble. De aí que a selección dos textos que se traducían estivese dirixida nun primeiro momento polas presións do nacionalismo literario e polas esixencias vixentes da posta en marcha dunha norma lingüística que lle outorgase estabilidade ao sistema. ("Imaxes" 52)

Discussions around "the Classics" / "universal literature" in literary translation in Galicia do not actually refer (or not usually) to the Greek and Roman Classics, but to works of authors that are understood as being part of the western canon of prestigious works. One can easily grasp, even without a clear definition, which authors are included here by looking at the authors translated and studied in the Galician literary system; Beattie 1999, in an article about the translation of James Joyce's Dubliners gives us some hints, as he discusses the inclusion of the work in the collection Grandes do noso tempo [Great Authors of Our Times]: "a propia colección concede o título de 'grandeza', medida en termos de traducción, non só a Joyce, senón tamén a outras figuras contempráneas tan sobresaíntes como Sartre, Camus, Gide, Pavese, Saint-Exupéry, Dylan Thomas e Salinger" $(50)^{14}$. A more recent example is provided by the works included in the catalogue of publisher Rinoceronte ${ }^{15}$, in particular their collections Colección clásica and Colección Vétera ${ }^{16}$ where all authors are male and western except for one, who is Japanese (an Asian colonial power, one should perhaps add $)^{17}$. These concrete examples are also supported by the

\footnotetext{
12 "One has to consider that translation is one of the most basic pillars of the dissemination (normalización) of the Galician language in all areas and fields [...], that is the reason why, purely economic or commercial considerations aside, translation has to be firmly and decidedly fostered by public administrations and find support in the private publishing sector" (All translations my own).

13 "The Galician literary system required, and still does, the support of the classics and of concrete themes, both in the production of originals, as well as in the field of translation, in order to support its weak structures. That is why the selection of texts to be translated was initially decided yielding to the pressures of the literary nationalist movement and the demands derived from the implementation of a language standard that could grant some stability to the system."

14 "The collection itself grants greatness, measured in terms of translation, not only to Joyce but also to other contemporary figures as remarkable as Sartre, Camus, Gide, Pavese, Saint-Exupéry, Dylan Thomas and Salinger.'

${ }^{15}$ Rinoceronte is a publisher specialising exclusively in translations into Galician.

${ }^{16}$ For a full title list, please refer to the publisher's website.

${ }^{17}$ For a detailed study of the evolution of the translated works published in Galicia please see Constenla Bergueiro 2013.
} 
discourse of different institutions, as the opening statement to the conference Lingua e traducion [Galician Language and Translation] by the then President of the Galician Royal Academy of the Language, Xosé Méndez Ferrín clearly shows. Méndez Ferrín (35-40) repeatedly refers in his speech to the literary canon and the authors (male and western) that are to be included in it and, therefore, translated into Galician. At this point it may become clear that recurring discussions around "universal literature" in Galicia assume a western male canon of hegemonic language authors, which is all the more paradoxical if one considers the situation of Galician literature itself, marginalised precisely in the name of such a canon.

However, the idea of normalizacion not only had an impact on the selection of the works translated, but also on the translators chosen for these tasks. As Constenla Bergueiro states in his analysis of the data gathered by the project Bitraga, a translation registry managed at the University of Vigo,

entre as persoas que se encargaron de anosar toda esta importante representación da literature universal atopamos unha boa cantidade de tradutores e tradutoras [...] cun perfil [...] medularmente semellante ao dos seus antecesores: profesorado de todos os niveis do ensino, escritores e escritoras, persoas relacionadas co mundo da cultura [...] e activistas a prol da lingua e cultura galegas. $(97)^{18}$

My own analysis (unpublished) of the self-perception of Galician literary translators regarding their role in the translation process underlines the role of normalizador/a as one of the most important elements in the self-perception of the translators studied. ${ }^{19}$ This is not surprising if we look at the profile of Galician translators furnished by Constenla Bergueiro above; Baxter (3-24) has already analyzed the gender implications of this particular framework, highlighting how women have traditionally been excluded from literary translation because of the close links between (patriarchal) nation-building and translation. This author offers an interesting critique of Chamberlain's theories, precisely emphasizing how, in the specific case of the Galician literary system, it is not predominantly women who have become literary translators, neither has translation been perceived as a secondary activity in some respects. The implications of his analysis will be further explored in the upcoming sections of this article.

Another important element for a proper contextualisation of the examples that will be presented later, and an element related to the framework introduced so far has to do with the excessive relevance that the literary system in general, and translation reviews and critiques in particular, give to linguistic aspects. Discussions on translation and translation analysis were and

\footnotetext{
18 "Amongst those who were in charge of translating (anosar) this important sample of universal literature, the majority of translators [...] had a profile [...] fundamentally similar to those who came before them: teachers and lecturers of all levels of the educational system, writers, people related to the cultural sphere [...] and Galician language and culture activists."

19 I conducted a systematic review of all the articles published in the journal Viceversa under the section Traducións xustificadas [Translations Explained], where literary translators are given space to discuss the aspects they deem interesting of their work in the translation of a particular book. The journal does not give translators any guidelines and, therefore, these reviews are really interesting in terms of how the translators see themselves and present their work when they are asked to do so.
} 
are regularly performed on the basis of how the language has been used, whether the enxebre ${ }^{20}$ [genuinely Galician] uses are preserved, whether the translator masters the Galician language. Meyer (n.p.) provides an interesting example of how his translation of Herta Müller's Der Mensch ist ein Grosser Fasan (The Passport in the English translation by Martin Chalmers) was harshly criticized because the language used was not enxebre enough, hinting at a shortcoming of the translator himself, who was therefore accused of lacking proper knowledge of the Galician language. However, if one goes back to the original, one sees that precisely one of the features of this work is the use of "broken German" (the main characters are German speakers in the Banat, Romania), and therefore the translator's apparent lack of knowledge of the Galician language was in fact his literary translation strategy for that particular (and indeed very relevant in the novel) feature. The trope of the translator as normalizador/a has thus become the foundation for the acceptance of translation strategies that prioritize the values of the target literary system, in this case a prioritization of linguistic criteria, without questioning the political implications of using those strategies without a specific analysis of each work and their position vis-à-vis Galician literature. Venuti (1992) refers to this as "domestication", but the Galician nationalist establishment had already coined a political term for this at the beginning of the $20^{\text {th }}$ century, Alvaro Cunqueiro's anosar (making something ours) ${ }^{21}$.

Nonetheless, there are other interesting aspects about the Galician literary system and translation that need to be addressed, such as, for example, the fact that Galicia has become a space for pioneering work in the field of feminist translation by researchers and practitioners such as Olga Castro (2009), Robert Baxter (2010), Marilar Aleixandre (see my discussion about her work later in this article), amongst others (see also Reimóndez 2009), and a space to question hegemony (see Montero Küpper 2013). Some translations of feminist works have been undertaken with lots of effort and care, be it the translation of Simone de Beauvoir's Le deuxième sexe by Marga Rodríguez Marcuño (critically analysed by Castro 2009) or several works by Virginia Woolf ${ }^{22}$. Edicións Xerais, one of the most important publishers in Galicia in terms of number of titles and social repercussion, also contributed to the enlargement of the feminist canon of translations with their collection As literatas (Bluestokings), which ran from 1999 to 2007 and included 14 titles. The collection's director was Galician feminist writer Maria Xosé Queizán and the collection's goal was to translate literary works by feminist writers. Its name comes from the novella, Las literatas, written by the founding figure of the Galician literary system, Rosalía de Castro (1837-1885), one of the strongest feminist voices not only in Galicia, but in Spain as a whole. This work in particular analysed the existing prejudice against female authors at the time it was written, whereby the title of the collection can also be read as a symbol of rebellion against the male literary canon of translated works. However, a cursory analysis of the works published looking at authorship may unmask a more complex web of power relations if

20 The definition of "enxebre" in the Galician Dictionary of the Royal Academy of the Language is as follows: "Characteristic of a country or region, without distortion, deformation or interference from something alien". Generally speaking it refers to the type of accent in spoken language, grammar (use of typically Galician forms such as infinitivos conxugados, and periphrasis only used in Galician vs Spanish and Portuguese), lexical elements (use of traditional ways of referring to things_-days of the week, for example_- use of very specific vocabulary for aspects related to Galician—usually rural—-traditional life_-designation of lands, terrains, rivers, fauna, etc-).

${ }^{21}$ See Álvarez Lugrís and Fernández Ocampo 1999 for a discussion of the origins of this term.

22 Woolf is no doubt the most widely translated feminist author in Galicia, with more than four works translated. 
observed from the point of view of postcolonial theories. As already mentioned, postcolonial theory looks at the construction of the colonial Other, both during and after "formal" colonization (Ashcroft et al. 1989), and its interactions with feminist theories have yielded works of outstanding theoretical value, such as those by Gayatri Spivak (1999), Chandra Talpade Mohanty (2003) and Gloria Anzaldúa (1987). Literature in particular has been an interesting area of both theory and practice, as critiques of colonisation and empire could and can be read through fictional texts in different ways. One of the literary forms that has been analyzed in more detail by postcolonial theories are so-called rewritings, i.e., the exploration of canonical works of the metropolis introduced in the colonies as part of the imperial enterprise from the perspective, precisely, of the (often formerly) colonized ${ }^{23}$. Jean Rhys' Wide Sargasso Sea, is one of those rewritings and is considered one of the most relevant works of the postcolonial feminist canon (McLeod 2000). This novel is also the only translated work by a postcolonial author included in the collection As Literatas, thus showing that the definition of the canon might have been challenged in terms of male authorship by the collection, but not in terms of other power inequalities such as colonial position and race.

The other work under study, Sandra Cisneros' Loose Woman (1994), was published by the same publishing house in their general collection for poetry, Ablativo Absoluto, a collection including mostly original works and translations (mainly of western authors). Out of the 22 titles in the collection, only 6 are translations (Cisneros being the only woman), while the rest were originally written in Galician (again the majority of these works were penned by men, with only 5 women authors in the Galician total).

\section{The Opposing Examples of Wide Sargasso Sea and Loose Woman}

The intersection between feminist and postcolonial theories, as we have briefly seen in the previous section, sheds light on new layers of power that are relevant for the configuration of literary canons, in this case for the specific example of the Galician literary system. Therefore, while in Galicia women in general were excluded from the canon both as authors to be translated and as translators, postcolonial women authors seem to have fewer opportunities still to be translated. The complete list of postcolonial works written by women and translated from English into Galician can further support this point $^{24}$, even if the inclusion of a white Anglophone Canadian author such as Erín Moure or Chicana literature is open to debate, but for the purpose of this analysis, and considering the position of Galician literature vis-à-vis these production sites, these works have been included in the list:

- Muller Ceiba ("Loose Woman”, 1994) by Sandra Cisneros, translated by Marilar Aleixandre for Edicións Xerais de Galicia in 1997.

- Entre o costume e a ruptura ("Of Customs and Excise", 1991) by Rachna Mara, translated by María Reimóndez for Edicións Xerais de Galicia in 1998.

- Luces Fóra (“Lights Out!”, 1984) by Manjula Padmanabhan translated by Antía Mato

23 The idea of the metropolis as the original and the colony as the imitation has also been fruitfully explored in postcolonial reflections on translation (see Bassnett and Trivedi 1999).

${ }_{24}$ The number of works by postcolonial women authors translated from other languages is practically negligible. 
Bouzas for Biblioteca Pillado Mayor in 2006.

- Ancho Mar de Argazo ("Wide Sargasso Sea", 1966) by Jean Rhys, translated by Manuel Forcadela for Edicións Xerais de Galicia in 2007.

- Teatriños ("Little Theatres", 2005) by Erín Moure, translated by María Reimóndez for Galaxia in 2007.

- A casa de Mango Street ("The House on Mango Street", 1984) by Sandra Cisneros, translated by Alicia Menéndez Sousa for Rinoceronte in 2008.

- O soño da sultana (“Sultana's Dream”, 1905) by Rokeya Sakhawat Hussain, translated by María Reimóndez for the Biblioteca Virtual Galega in 2010.

- A bistoria de Mary Prince ("The History of Mary Prince", 1831) by Mary Prince, translated by María Reimóndez for the Biblioteca Virtual Galega in 2010 (Plácido Castro Translation Award).

The list of works already seems to suggest that not much attention has been paid to the political importance of including non-western authors in the canon of translated feminist works in Galician. However, this is not the only important aspect one needs to consider, as the objective of this article is also to explore the translation strategies applied to such texts and how they support or subvert the general framework presented so far, especially in terms of the power assigned to authors and translators. I have chosen the examples of Wide Sargasso Sea and Loose Woman because they constitute opposing approaches to the postcolonial feminist Other, and thus contribute to a nuanced exploration of the Galician literary system as a site of struggle in its double hegemonic-non hegemonic position.

The first example I will analyze is the translation of Wide Sargasso Sea by Galician poet Manuel Forcadela, published, as already indicated, in As Literatas as the outcome of an unfortunate and tortuous process ${ }^{25}$. Forcadela's translation includes a foreword, as is the case for most of the books in this collection, even if sometimes the foreword is not by the translator but by a literary expert (usually when the translator is not herself or himself a writer). The foreword does not directly address translation as such, but verges rather on a purely literary introduction to Jean Rhys and her novel. Despite this apparent lack of information about the translating process itself, the foreword is quite telling regarding Forcadela's position as translator, for example in the lack of a proper contextualization of Wide Sargasso Sea as a rewriting of Charlotte Brontë's Jane Eyre. He mentions this only in passing in the sentence: "Deste xeito Rhys humaniza a imaxe da crioula louca de atar que Brontë pintaba en Jane Eyre, invitándonos a simpatizar coa quebra mental dunha muller solitaria e incomprendida" 26 (Forcadela 12). Considering the immense impact that Wide Sargasso Sea had on the English-language feminist canon ${ }^{27}$, this absence of

\footnotetext{
25 According to the publisher, Manuel Bragado, the translation of Wide Sargasso Sea was initially suggested by Marta Pérez Pereiro, a degree-holder in English Philology, who actually submitted a translation of the text, which was rejected by María Xosé Queizán for reasons that are unclear to the publisher. The task was then assigned to renowned translator Xela Arias, but unfortunately she died before completing the work, and once again it was Queizán who assigned the translation to Manuel Forcadela. (personal communication with the publisher, Mr Manuel Bragado).

${ }^{26}$ In this way, Rhys humanizes the image of the mad Creole woman who Brontë presented in Jane Eyre, inviting us to sympathize with the mental breakdown of a solitary and misunderstood woman.

${ }_{27}$ Gilbert and Gubar 1979 use the image of the "madwoman in the attic" to study English-language women authors
} 
contextualization strikes the reader as odd to say the least. Rhys' rewriting of the character of Bertha Mason, the mad woman in the attic, the obstacle to Jane's marriage to Rochester in Jane Eyre, marked the beginning of a systematic review of how the celebration of some female and feminist authors in the English-language canon had actually not taken into consideration how their subjectivity was based on the erasure of the colonised Other (see, for example, Spivak 1999). Thus, Jane Eyre was celebrated by the white feminist canon, forgetting that the logic of the novel rested on the oppression of the Creole madwoman brought to England by Rochester from the Caribbean. Rhys' text not only reinscribes the colonized female Other in this narrative, she actually subverts with her text the idea of a single (white, middle-upper class, heterosexual) feminist subjectivity. The whole body of postcolonial feminist scholarship around the novel is then dismissed by Forcadela in one sentence, while conflicts related to gender and race, so strongly present in the novel, are similarly presented by the translator as "universal problems", therefore making it impossible for a Galician reader to understand the context of postcolonial critique the novel stems from ${ }^{28}$. An example of this is the translator's representation of the relationship between Antoinette and her husband ${ }^{29}$ as if their contexts, choices and positions were equal: "tanto Antoinette como o seu home son seres rexeitados pola familia, deitados sobre o taboleiro da vida a xogar unha indecisa partida de azar e de loucura" (11). ${ }^{30}$

An analysis of the actual translation will give a clearer idea of the translator's position regarding the author and the text, beginning with the problematic issue of "unequivocal errors" or specific choices in the translation that no possible interpretation range could justify. The number of unequivocal errors (approx. 300 in a book of under 200 pages) already demonstrates a degree of carelessness by the translator and the whole editorial process that seems to suggest that this author was perhaps not deemed worthy enough to deserve extensive proof-reading (or at least a competent translator) to ensure minimum standards of quality. While of course one may argue that there may be many other deficient translations in the Galician market, the fact is that once an author is considered important by the establishment, proof abounds of the relevance given to who translates and how the work is translated. ${ }^{31}$

The unequivocal errors included in this translation are also far from the minor mistakes any translation might contain, even with a good editorial process in place. Errors include

of the $19^{\text {th }}$ century.

${ }^{28}$ For example, the novel is not described in the context of colonization but as a story that tries to "diluír as fronteiras entre o mito e o logos" ("dilute the frontier between myth and logos") (7).

${ }^{29}$ Antoinette is Bertha Mason; in Wide Sargasso Sea it is her husband, who is never addressed by name but who is obviously Rochester in Jane Eyre, who changes her name to Bertha. Antoinette is an impoverished Creole heiress in the Caribbean, while Rochester is a white English man who agrees to marry her, and later takes her to England with him. Their positions are therefore quite far from being comparable in the historical moment the novel is set in, the 1830s, just after the abolishment of the Slavery Act by Great Britain.

30 "Both Antoinette and her husband are beings rejected by their families, set upon the chessboard of life playing an open game with chance and madness." Presenting gender-related conflicts as general instances of violence is a recurring patriarchal strategy that deactivates, for example, the mobilisation of citizens against gender violence (see Lorente).

31 See for example the case of Shakespeare's Sonnets, published in a facsimile edition, painstakingly edited and translated by Ramón Gutiérrez Izquierdo whose translations were included in the volume Shakespeare's Sonnets Global (Edited by Manfred Pfister and Jürgen Gutsch). The Galician edition includes a detailed commentary of the Sonnets, and other signs of status for a translation. Further examples include the translations of Dante and Petrarch by Darío Xohán Cabana. 
instances of stating the complete opposite of what is said: "and I was glad" (26) becomes "eu estaba triste" (29) ("I was sad"); changing the subjects of the action such as: "he knew what they were going to do" (16) becomes "sabías o que ían facer" (17) ("you knew what they were going to do") or direct changes of the actual plot, the most remarkable being: "What is the huge bundle on her head?' 'Her mattress,' said Baptiste" (117), which becomes "Que é ese enorme fardo que leva na cabeza? - A súa ama—dixo Bautista" (137-138) "What is that huge bundle on her head?" "Her mistress", said Baptiste). It is interesting to note that most of these errors occur precisely in the parts where Antoinette is the narrator.

However, one gains a better understanding of the translator's position through a more detailed analysis of concrete translation choices beyond unequivocal errors. It is here where Forcadela's position as the white, male, powerful translator really surfaces, as we shall see in the following examples. A relevant aspect to support this claim is the systematic attenuation of instances of violence against women described in the original novel; the translator intervenes on several occasions from this particular perspective. For example, when Antoinette's stepfather carries her mother out of the house in flames where Pierre, Antoinette's brother, is dying. Rhys describes this moment as: "he [Mason] half supported, half pulled her after us, cursing" (35). Forcadela translates this as "medio sosténdoa, medio, abrazándoa, tróuxoa ata onde nós estabamos, gritando con forza" ("half supporting her, half embracing her, he brought her to where we were, shouting strongly"), whereby "pulling" becomes "embrace" and "cursing", just "shouting." Another example can be seen in the segment where the male protagonist (Rochester) tries to go into Antoinette's room: "I tried the door into Antoinette's room" (88); in Galician he politely knocks on the door: "Chamei á porta" (103). The attenuation of physical / sexual violence is also present in the translation, for example, when Antoinette's husband justifies his sexual brutality towards her as "That was love's fierce play" (136); in Galician this becomes "Aquilo era o drama da forza do amor" (161) ("That was the drama of love's force") where the violence of the image is once again diluted. Patriarchal violence is once again blurred when Christophine repeatedly tells Antoinette's husband: "And then you want to break her up" (125), expressing the psychological violence he is exercising over Antoinette, while the translation reads: "E entón vostede quere separarse" (148) ("And then you want to get a separation from her"), showing a clear misunderstanding by the translator of "break up" as "breakup".

To add one final example, it is interesting to look at one of the most widely studied moments in the novel, the renaming of Antoinette as Bertha, her mother's name, by her husband, thereby burdening her with the stigma of her mother's madness. Antoinette is explaining at one point precisely that Bertha "was my mother's name" (94), but in Galician this reads "era o apelido da miña mai" (109) ("was my mother's surname”), thus making it very difficult to understand the implications of this symbolic gesture.

Another aspect that shows the power position of the white male translator vis-à-vis Rhys' text are his choices involving several race-related features. The novel is actually built upon a complex and nuanced portrayal of racial relations at a time when the frontiers between the groups (blacks, Creole, whites) were becoming increasingly blurred. One of the ways Rhys achieves this high level of complexity in the representation of race is through the language used 
by the different characters, in particular the distinction between those characters speaking in Creole (usually black, but also Antoinette) and those using English (usually white British characters). The translator does not preserve any trace of these racial markers in his text; while it is indeed difficult to find a way to do this in Galician, a language that does not have anything similar to a Creole in its repertoire, at least the translator could have mentioned this aspect in the foreword.

Rhys also examines racial relations in the novel through a very complex use of terms related to race such as "black", "nigger", "negro", "coloured", which just become "negra/o" (for the first three) and "mulata/o" (for the last one). The same kind of lack of attention to race in the translation can be seen in the way the terms "boy" and "girl" when referring to black servants have been translated, especially considering that Rhys' criticism of those terms tends to come in the introduction of several comments by characters mentioning the actual age of these "boys" and "girls", thus highlighting the belittling implications of these words in their racial context. The translator, however, uses all kinds of synonyms to translate these two terms, effectively making it impossible to understand that the term does not refer to the age of the person, but to their colour and social position. In a conversation Antoinette holds with Rochester, she explains, referring to the servants: "The girls here are very shy" (75). In Galician this is rendered as "Aquí as raparigas son moi tímidas" (87), thus implying that young women in the island are very shy. While the term "rapaza" has been used in history to refer to (white) servants, "rapariga" only refers to the age of the person and does not imply anything else.

Still more problematic is the translation of statements in which it is the translator who introduces racist connotations, such as, for example, during Antoinette's description of her black nurse Christophine in the following terms: "She had a quiet voice and a quiet laugh (when she did laugh)" (18), translated as: "Tiña unha voz grave e un riso grave, cando ría. E aínda." (19) ("She had a deep voice and a deep laugh, when she laughed. And even then"). However, when white characters make explicit racist comments, the translator seems to feel uncomfortable and systematically removes them, a significant example of this trend being the moment when the male protagonist asks Antoinette why she kisses Christophine, a black woman: "I wouldn't hug and kiss them" (76, emphasis in the original). It is clear that the husband's objections do not have to do with Christophine as an individual, but with the fact that she is black, clearly marked by the "them". In Galician this becomes: "-Eu non a abrazaría nin a beixaría” (88) ("I would not hug her or kiss her"), which effectively erases this distinction between the individual and the systemic nature of racism.

The fact that the white male translator feels free to translate a postcolonial feminist author against the grain can be further explored in how the image of Antoinette is deeply altered in the Galician text, actually reinforcing the idea that Antoinette is mad, while the original text seems to be trying to subvert precisely that idea. The translator finally achieves this effect by systematically translating different expressions or descriptions about Antoinette that have nothing to do with madness with "tola", "louca" and their related verbs. Some examples are: "She run wild" (22), as "Que estaba a enlouquecer" (24) ("She was going crazy"); "You fool the girl" (126) as "e toleou a rapariga" (148) ("you drove the girl crazy") or "a rich white girl like you 
and more foolish than the rest" (91) as "Unha rapariga branca e rica coma ti e máis louca que as demais" (106) ("madder than the rest").

At this point it seems clear that the translator's interpretation of the text stems from a colonial and patriarchal position of superiority, an aspect that is actually quite tangible in the way he has literally erased women from the translated text. Apart from the-otherwise quite frequent-strategy of translating any gender neutral name in English into the masculine, the translator went as far as to masculinize terms that had clear female references. When Antoinette claims, speaking about herself and her mother: "I knew we were hated" (27), the Galician translation reads "Sabiamos que eramos odiados" (30), in the masculine. The same phenomenon can be seen in the sentence Antoinette's husband tells Christophine: "Your doudou certainly know" (128): as Doudou is the pet name Christophine has for Antoinette, the translation as "O teu doudou coñece" (151), in the masculine, once again contributes to the invisibility of the female characters.

The erasure of the female voice and general lack of attention to gender in this translation is perhaps best exemplified by the case of the two characters whose gender is changed in the translation. The first instance is found at the end of the novel, when the voice of Grace Poole, the woman in charge of keeping Antoinette/Bertha locked up in the attic, explains: "The servants were sent away and she engaged a cook, one maid and you, Leah", the translation mentions "un cociñeiro" (170), i.e. a male cook, although anybody who has read Jane Eyre knows that the cook is a woman, Mary. The other example is still more remarkable, as one of the servants, Mannie, is sometimes referred to in the feminine and sometimes in the masculine in the translation, even if the original makes it very clear that Mannie is a man: "A stone just missed Mannie's head, he cursed back at them" (emphasis added) (35); "Unha pedra pasou rozando a cabeza de Mannie. Ela deuse a volta e maldiciunos" (41) ("She turned around and cursed them"), while in page 42 he is once again referred to as a man.

A final element in this discussion of the position of Forcadela as translator of Jean Rhys may only be understood in light of my previous discussion of the discourse of normalización in Galician translation, which tends to entitle translators to "correct" the original, introducing "improvements" in the name of a proper use of the Galician language. This particular translation is a clear example of this, with 540 significant alterations of the original punctuation, most of the time shortening Rhys' sentences, especially when Antoinette is the narrator. These interventions stand in contradiction to the outcomes of comparative studies on the translation between English and Galician, whereby Galician sentences tend to be longer than English ones, as the reflections by John Rutherford, director of the Translation Workshop at Queen's College, Oxford, show: "é unha práctica común entre os tradutores ingleses dividir as oracións longas do texto orixinal e así crear oracións curtas, o cal é outro exemplo de domesticación excesiva" $(219)^{32}$. When this is seen in combination with the opposing trend of making highly complex sentences when the characters use Creole or "broken English", the logic of these interventions as "improvements" of the original work seems quite clear.

\footnotetext{
32 It is common practice that English [sic] translators divide the long sentences in the original text and thus create short sentences, which is another example of excessive domestication.
} 
While in many of the analyses of translated works by postcolonial Others the voice of the translator can only be glimpsed through the specific choices made in the text, in this case the above-mentioned issues can be further understood by looking at Manuel Forcadela's explanation of how the translation was performed. Forcadela is one of the translators who submitted an article to the section Traducións xustificadas of the journal Viceversa, precisely to discuss the translation of Wide Sargasso Sea. The article is worth reading in full, as it shows to what extent Forcadela felt entitled to work with Rhys' text without having the least awareness of the gender and race critique it suggests. One quote from this text suffices to substantiate the analysis derived from the specific examples presented above, in particular the moment when Forcadela explains what he thought he was expected to do as a translator with Rhys' text: "a principal resistencia [when translating the text] era producir un texto no que o galego literario estivese á altura do inglés literario orixinal. Dito con outras palabras, o estilo de Jean Rhys precisaba do meu estilo" (2007: 237, emphasis added) ${ }^{33}$. This quotation is relevant as it supports the argument that in Forcadela's mind his work as translator was to improve a text that was, according to him, deficient from the start.

A completely different position in the mediation of a text by a postcolonial Other is shown by Marilar Aleixandre in her translation of Sandra Cisneros' Loose Woman. Cisneros' work, and this poetry collection in particular, belong to Chicana literature, an open feminist movement challenging the borders of the languages, concepts and cultures they are supposed to belong, in exclusionary terms, to Mexican culture on the one hand, and white US culture on the other. Gloria Anzaldúa developed the concept of frontera to define that space of in-betweeness and rebellion, a space for self-definition in which hybrid languages play a key role. Loose Woman also plays with the sexual derogatory tone of the term, and subverts it to claim an open and powerful female sexuality. These aspects will prove interesting for the analysis of the translation of the work into Galician, as we will see in the following lines. One has to first consider that the translation of the work was initiated by the translator herself, something not uncommon in Galicia (see Martín Lucas et. al 2012), and also as an endeavour understood in the framework of translation as feminist collaboration (von Flotow). Aleixandre first read some texts by Cisneros on a trip to the US and suggested the translation of those texts to María Xosé Queizán, editor of the feminist magazine Festa da palabra silenciada [Celebration of the silenced word], who contacted Cisneros to get approval for the translations. It was then that Aleixandre decided to discuss the possibility of translating Loose Woman for the poetry collection Ablativo Absoluto of Edicións Xerais de Galicia and the text was finally published as a bilingual edition in 1997 (personal communication with Aleixandre). The Galician translation of the work includes an introduction by Aleixandre, where she links the idea of a loose woman to that of a loose translation, precisely subverting the traditional opposition to "literal" translation with a redefinition of the term as a translation that is wild, sexual, female and uncontrollable (Aleixandre 5). The introduction also highlights two important aspects of Aleixandre's approach to the text: the need to preserve the otherness in Cisneros' text and her explicit choice of finding a connection to the Galician literary system in general, and its feminist movements in particular. In the introduction, Aleixandre acknowledges the wild voice of a woman claiming her sexuality and her place between cultures; a

33 "The most important resistance was to produce a text in which the literary Galician was on the same footing as the literary English of the original. In other words, Jean Rhys' style needed my style"”. 
voice she links to other Galician writers such as those present in the Batallón Literario da Costa da Morte and A Festa da palabra silenciada ${ }^{34}$ itself, and women poets such as Sylvia Plath or Anne Sexton. From this perspective, Aleixandre reflects on how this position affected her work from the translation of the title itself:

Loose woman» [...] podería ser muller licenciosa, descarada, libertina, ou libre, mais que finalmente, despois de discutilo [...] decidín traducir como "ceiba". "Ceiba" ten outras connotacións en galego, ademais do significado literal, evoca o contexto de "Viva Galicia ceibe ${ }^{35}$. [...] Unha muller ceiba é libre, e ademais libertina e descarada como a de Sandra ${ }^{36}$. (Aleixandre)

The translator is also concerned about the hybrid nature of Cisneros' text and the political implications of such hybridity. Therefore, her approach is not that of a translator who wants to normalizar or anosar, but that of a translator trying to create a space that is also a frontera, in Anzaldúa's terms. Aleixandre uses different strategies to achieve this goal, the first being her skilful preservation of "broken" Mexican Spanish without attempting to "correct" (except for minor instances) Cisneros' own language. One needs to consider here that Spanish is precisely the hegemonic language that has the largest influence on the subordination of Galician, and as such the preservation of such hybrid forms present in Cisneros' text (and the fact that hers is not the peninsular variety of Spanish) create an interesting effect. By making the language sound close and far at the same time, the presence of these fragments question absolute concepts of linguistic oppression, showing how, while Galician in Spain and indigenous languages in Mexico are oppressed by the Spanish language, in Cisneros' work it actually becomes the vehicle for the subordinated Other. However, Aleixandre's concern for hybridity runs deeper in the text, as she chooses her words from a large variety of registers that immediately distance her from the image of the translator as normalizadora. The translator uses terms from medieval texts (arreite, for example, to translate "hard-on"), from highly colloquial registers ("papándonos enteiros o un, / ó outro" (65) for "swallowing each other / whole" 64), and she also looks for the echoes of the text in Galician references, such as "And now the good times are coming. Girl, / I tell you, the good times are here" (130) as "E agora chegan os bos tempos. Moza, / dígocho, os bos tempos son chegados" (131), with this last sentence taking the Galician reader to a verse in the Galician national anthem, widely used to speak about the revival of Galician culture. ${ }^{37}$ The sexual references in Cisneros' text also establish connections, in Aleixandre's translation, to the female poets writing in Galicia at the time the translation was published, popularly known as the xeracion dos 90 [90s Generation], in which women poets used crude images to take control over their

\footnotetext{
34 The Batallón literario da Costa da Morte [Literary Battalion of the Costa da Morte] was a group of both male and female poets linked to this part of Galicia, who used to organize recitals and produce poetry collections together. $A$ Festa da palabra silenciada is a feminist journal where essays, poetry and reviews are published. Aleixandre participated in both.

35 A slogan for independence and for cultural movements in Galicia.

36 "Loose Woman [...] could be a shameless, bold, libertine or free woman, but after discussing it [...] I decided to translate it as 'ceiba'. 'Ceiba' ('free') has other connotations in Galician, apart from its literal meaning it evokes the context of 'Viva Galicia Ceibe' ('Long live free Galicia!'). A 'ceiba' woman is not only free, but also libertine and shameless, just like Sandra."

37 The Galician national anthem is the poem "Os pinos" by Eduardo Pondal and one of its verses reads: "Os tempos son chegados / dos bardos das edades / que as vosas vaguedades/ cumprido fin terán" ("The times have come / for the bards of the ages/ to bring your vagueness/ to a well-deserved end").
} 
bodies through poetry. ${ }^{38}$ Aleixandre also disrupts Galician grammar in the same way Cisneros disrupts the grammar of the languages she uses, as we can see in the example of the poem "You Bring Out the Mexican in Me" (14), with its version by Cisneros in broken Spanish in one of the verses as "Me sacas lo mexicana en mín" (16), which in Galician becomes "Tiras fóra a mexicana en min", a sentence that keeps a foreignness to it, like Cisneros'.

This brief study of all these strategies reveal Aleixandre's position as one in line with the idea of translation as "feminist collaboration", not only because she had some direct contact with Cisneros throughout the process but, more precisely, because the strategies used are attentive to the position of Cisneros' text in the Chicana literature and, more importantly, to her own position as mediator in the process.

\section{Conclusions}

The two examples presented in the previous section help draw several conclusions regarding the risks and potential for the translation of works written by postcolonial women in literary systems such as the Galician one. Apart from the concrete implications of these examples, if translation is to be understood as an activity that is central to postcolonial feminist solidarity, as Gayatri Spivak argues in "The Politics of Translation" (2004), then specific translation positions and strategies have to be at the heart of theoretical discussions.

Translations such as that by Manuel Forcadela not only place the white male translator in a privileged position to bolster the agenda of patriarchal imperialism, they also deactivate the potential for connection across borders that texts such as Wide Sargasso Sea could actually foster. The reflections on colonization, racism and the construction of white, western, female subjectivity that the novel presents could no doubt help the Galician feminist movements critically analyze the links between colonization and patriarchy that they still need to subvert. Such texts also have the potential to reassess Galician identity as an identity that cannot forget its responsibility towards non-white, non-Western women, despite its own position as a nonhegemonic nation. The fact that Galician literature and culture stand at the cross-roads of hegemony, as Montero Küpper rightly argues, implies that such reflections can also have an immense potential to overcome Galicia's marginal position, and establish more fruitful links that need not follow the paths marked by the centre:

Abandonar a hexemonía cultural significa colocármonos nunha situación privilexiada xa que nos permite ampliar o noso horizonte cultural completando, no caso da importación de textos alleos, o espectro literario e científico que ofrece a cultura dominante á par que a nosa alteridade se volvería patente no tocante á exportación da nosa cultura. ${ }^{39}$ (59)

In the wake of Mohanty's concept of "feminist solidarity" (221-252), which is precisely based on

\footnotetext{
38 Authors include Olga Novo, Lupe Gómez, Yolanda Castaño. See González (2001).

39 "Leaving cultural hegemony behind means placing ourselves in a privileged position, as we can expand our cultural horizon completing, in the case of the import of foreign texts, the literary and scientific spectrum that the hegemonic culture offers, while our alterity would become visible for the export of our culture."
} 
an understanding of position and of the histories and contexts of the Other, feminist postcolonial translation becomes an urgent political endeavour that calls for more detailed attention to how texts from postcolonial women authors are translated. Marilar Aleixandre's strategies already present interesting examples of how a reflection on position and an attentive, non-colonial contact with the Other can yield texts that question the boundaries of the literary cannon and establish connections with the Galician feminist literary tradition without erasing the Other. Feminist translation projects understood in this way have the potential to challenge the borders of who is allowed to speak in the Galician nation and what relationships we want to establish with our non-hegemonic Others. 


\section{REFERENCES}

Abdulla, Adnan K. "Aspects of Ideology in Translating Literature.” Babel 45.1 (1999): 1-16. Web.

Aleixandre, Marilar. "Escándalo, Espiral.” Introduction. Muller Ceiba. Vigo: Xerais De Galicia, Ediciones, 1997. 5-7. Print.

"As Preguntas." Message to the author. N.d. E-mail.

Alighieri, Dante. A Divina Comedia. Trans. Darío Xohán Cabana. Lugo: Edicións Da Curuxa, 2014. Print.

Álvarez Lugrís, Alberte and Anxo Fernández Ocampo. Anovar/Anosar Estudios De Traducción E Interpretación. Vigo: Universidade De Vigo, 1999. Print.

Ambai. "To Pierce a Mustard Seed and Let in Seven Oceans." Translating Women. Indian Interventions. Ed. N. Kamala. New Delhi: Zubaan, 2009. 63-67. Print.

Anzaldúa, Gloria. Borderlands = La Frontera. San Francisco: Aunt Lute, 1987. Print.

Arrojo, Rosemary and Harish Trivedi. "Interpretation as Possessive Love. Hélène Cixous, Clarice Lispector and the Ambivalence of Fidelity." Postcolonial Translation. Ed. Susan BassnettMcGuire. London and New York: Routledge, 2009. 141-61. Print.

Ashcroft, Bill, Gareth Griffiths and Helen Tiffin. The Empire Writes Back: Theory and Practice in Post-colonial Literatures. London: Routledge, 1989. Print.

Bassnett-McGuire, Susan and Harish Trivedi. Postcolonial Translation. London and New York: Routledge, 2009. Print.

Baxter, Neal. "Approaching Androcentrism in Galician Translation: Trends and Patterns." Galicia 21 Journal of Contemporary Galician Studies B (2010): 3-24. Web. 2 April 2015.

Beattie, John. "Escribir E Traducir Na Periferia: O Caso De Dubliners De James Joyce En Galego." Viceversa. Revista Galega De Tradución 5 (1999): 49-60. Print.

Callón, Carlos. “O Galego No Traballo.” Galicia Hoxe. N.p., n.d. Web. 2 April 2015.

Castro, Olga. "Ideoloxías Textuais E Paratextuais Nas Traducións De Le Deuxième Sex De Simone De Beauvoir.” Viceversa. Revista Galega De Tradución 12 (2009): 49-78. Print.

Chamberlain, Lori. "Gender and the Metaphorics of Translation." Signs: Journal of Women in Culture and Society 13.3 (1988): 454-72. Web.

Cisneros, Sandra. Loose Woman: Poems. New York: Knopf, 1994. Print. 
Muller Ceiba. Trans. Marilar Aleixandre. Vigo: Xerais De Galicia, Ediciones, 1997. Print.

Constenla Bergueiro, Gonzalo. "Evolución das traducións ao Galego: das orixes ao século XXI." Lingua e tradución. Ed. Xesús Mosquera Carregal. A Coruña: Universidade da Coruña, 2013. 83-100. Print.

Cronin, Michael and Edwin Gentzler. "The Empire Talks Back: Orality, Heteronomy and the Cultural Turn in Interpretation Studies." Translation and Power. Ed. Maria Tymoczko. Amherst: University of Massachusetts, 2002. 45-62. Print.

Dasilva, Xosé Manuel. Babel Entre Nós. Escolma De Textos Sobre a Traducción En Galicia. Vigo: Servicio de Publicacións da Universidade de Vigo, 2003. Print.

- Babel entre nós. Escolma de textos sobre a traducción en Galicia, Vigo: Servicio de Publicacións da Universidade de Vigo, 2003. Print.

Dizon, Lino and José Rodríguez. Cruceiro : Spanish Galicia at Some Crossroads in Philippine History and Culture (1521 - 1898). Angeles City: Center for Kapampangan Studies, Holy Angel U, Philippines, 2011. Print.

Even-Zohar, Itamar. "A Posición Da Traducción Literaria Dentro Do Polisistema Literario." Viceversa. Revista Galega De Tradución 2 (1996): 59-65. Print.

Fernández Prieto, Lourenzo. "Interpreting Galician History: The Recent Construction of an Unknown Past." Contemporary Galician Cultural Studies: Between the Local and the Global. Eds. Kirsty Hooper and Manuel Puga Moruxa. New York: Modern Language Association of America, 2011. 24-39. Print.

Figueroa, Antón. "National Literature and Literary Field." Contemporary Galician Cultural Studies: Between the Local and the Global. Ed. Kirsty Hooper and Manuel Puga Moruxa. New York: Modern Language Association of America, 2011. 40-53. Print.

Flotow-Evans, Luise Von. Translation and Gender: Translating in the "Era of Feminism". Manchester: St. Jerome Pub., 1997. Print.

Forcadela, Manuel. "Traizoar a Jean Rhys.” Viceversa. Revista Galega De Tradución 13 (2007): 23542. Print.

“Fundación Amancio Ortega.” Fundación Amancio Ortega. N.p., n.d. Web. 04 June 2015.

Gilbert, Sandra M. and Susan Gubar. The Madwoman in the Attic: The Woman Writer and the Nineteenth-century Literary Imagination. New Haven: Yale UP, 1979. Print.

Gobierno de España. Ley Orgánica 8/2013, de 9 de diciembre, para la mejora de la calidad Educativa. 
Madrid. 2013.

González Millán, Xoán. “Cara a Unha Teoría Da Traducción Para Sistemas Literarios 'marxinais’. A Situación Galega.” Viceversa. Revista Galega De Tradución 1 (1995): 63-72. Print.

González, Helena. A Tribo Das Baleas. Poetas De Arestora. Vigo: Xerais, 2001. Print.

Hooper, Kirsty and Manuel Puga Moruxa. "Introduction: Galician Geographies." Contemporary Galician Cultural Studies: Between the Local and the Global. New York: Modern Language Association of America, 2011. 1-16. Print.

“IGE - Enquisa De Condicións De Vida Das Familias. Coñecemento E Uso Do Galego.” IGE Insituto Galego De Estatística, n.d. Web. 02 April 2015.

Iglesias Álvarez, Ana. "Actitudes E Prexuízos Lingüísticos En Galicia. A Súa Influencia Nos Usos. " A Letra Miúda. Revista De Sociolingüistica Para O Ensino 1 (2012): n. p. Web. 2 April 2015.

Ives, Peter and Rocco Lacorte. Gramsci, Language, and Translation. Lanham, MD: Lexington, 2010. Print.

"La LOMCE Relega Las Lenguas Cooficiales a 'asignatura De Especialidad" - Educaweb.com. N.p., n.d. Web. 02 Apr. 2015.

Lezcano, Arturo. "Haití: O Soporte Espiritual Dun Pobo.” Luzes [A Coruña] Oct. 2014: 12-19. Print.

Lombao, David. “O Galego Deixa De Ser a Lingua Habitual Da Maioría Da Poboación - Praza Pública.” Praza Pública. N.p., n.d. Web. 02 April 2015.

López Silva, Inma. Maternosofía. Vigo: Galaxia, 2014. Print. Memoria Das Cidades Sen Luq. Vigo: Galaxia, 2008. Print.

Lorente, Miguel. Autopsia. N.p., n.d. Web. 2 April 2015.

Luna Alonso, Ana. "Imaxes E Representacións Do Outro: A Literatura Galega Cara ás Linguas Do Estado Español.” Anuario Grial De Estudos Literarios Galegos (2003): 52-59. Print.

. "Análise da tradución literaria cara ao Galego. Fitos e tendencias nos primeiros anos do século XXI." Lingua e tradución. Ed. Xesús Mosquera Carregal. A Coruña: Universidade da Coruña, 2013. 101-126. Print.

Macedo, Donaldo P., Bessie Dendrinos and Panayota Gounari. The Hegemony of English. Boulder, CO: Paradigm, 2003. Print. 
Martín Lucas, Belén, Erín Moure and María Reimóndez. "Canada in Galicia? Or Galicia in Canada? Translating Erín Moure." Canada and Beyond 2.1-2 (2010): 69-95. Web. 2 April 2015.

McLeod, John. Beginning Postcolonialism. Manchester, U.K.: Manchester UP, 2000. Print.

Méndez Ferrín, Xosé Luís. "A internacionalización da cultura galega." Lingua e tradución. Ed. Xesús Mosquera Carregal. A Coruña: Universidade da Coruña, 2013. 35-40. Print.

Meyer, Franck. "Siddhartha En Galego." Viceversa. Revista Galega De Tradución 7-8 (2002-2003): n.p. Print.

Mohanty, Chandra Talpade. Feminism without Borders: Decolonizing Theory, Practicing Solidarity. Durham: Duke University Press, 2003. Print.

Montero Küpper, Silvia. “As políticas de tradcuión no caso Galego." Lingua e tradución. Ed. Xesús Mosquera Carregal. A Coruña: Universidade da Coruña, 2013. 41-62. Print.

Naranjo Orobio, Consuelo. "Los Trabajos Y Los Días: Colonos Gallegos En Cuba En El Siglo XIX.” SEMATA. Ciencias Sociais E Humanidades 11 (1999): 191-215. Print.

Noia Campos, Camino. "Historia Da Tradución En Galicia No Marco Da Cultura Europea." Viceversa. Revista Galega De Tradución 1 (1995): 13-62. Print.

O'Rourke, Bernadette. "The Galician Language in the Twenty-First Century." A Companion to Galician Culture. Ed. Helena Miguélez-Carballeira. Woodbridge: Tamesis, 2014. 73-92. Print.

Petrarca, Francesco. Cancioneiro. Trans. Darío Xohán Cabana. Lugo: Edicións Da Curuxa, 2013. Print.

Reimóndez, María. A Alternativa Está Aquí. Vigo: Xerais, 2014. Print.

- "Monolingual] Sounds, [No] Translation as Subversion and the Hope for Polyphon." The Transnational Story Hub: Between Self and Other. Ed. Merlinda Bovis. N.p.: Forthcoming, 2013. N. pag. Print

- "The Curious Incident of Feminist Translation in Galicia: Courtcases, Lies and Gendern@tions.” Galicia 21 Journal of Contemporary Galician Studies A (2009): 68-89. Web.

Rhys, Jean. Ancho Mar De Argazo. Trans. Manuel Forcadela. Vigo: Xerais, 2007. Print Wide Sargasso Sea. London: Penguin, 1993. Print.

Risco, Vicente. El Oriente Contado Con Sencillez: N.p.: n.p., n.d. Fundación Vicente Risco. Web. 2 April 2015. 
Rivas, Manuel. Mobicania. A Coruña: Edicións Do Rueiro, 1986. Print.

Robinson, Douglas. Translation and Empire: Postcolonial Theories Explained. Manchester, U.K.: St. Jerome, 1997. Print.

Rutherford, John. "O Obradoiro De Tradución Do Queen's College Da Universidade De Oxford (á Memoria De Mr Knight)." Viceversa. Revista Galega De Tradución 16 (2010): 217 25. Print.

Said, Edward W. Orientalism. New York: Vintage, 1979. Print.

Sánchez Aríns, Susana. "Maternosofia: Suficiência Racional vs. Instinto Maternal A Sega." $A$ Sega. n.p. Web. 2 April 2015.

Shakespeare, William. Sonetos De Shakespeare: Shakespeare's Sonnets. Trans. Ramón Gutiérrez Izquierdo. Vigo: Edicións Xerais De Galicia, 2011. Print.

Spivak, Gayatri. “The Politics of Translation.” The Translation Studies Reader. Ed. Lawrence Venuti. New York: Routledge, 2004. 369-88. Print.

- A Critique of Postcolonial Reason: Toward a History of the Vanishing Present. Cambridge, MA: Harvard University Press, 1999. Print.

. "Can the Subaltern Speak?" Marxism and the Interpretation of Culture. Ed. Cary Nelson and Lawrence Grossbert. Urbana: U of Illinois, 1988. 271-313. Print.

Tymoczko, Maria and Edwin Gentzler. Translation and Power. Amherst: University of Massachusetts, 2002. Print.

Vázquez Padín, Carlos. “O Exemplo De Inditex.” A Peneira Dixital. N.p., 18 June 2012. Web. 2 April 2015.

Venuti, Lawrence. Retbinking Translation: Discourse, Subjectivity, Ideology. London and New York: Routledge, 1992. Print.

Xunta de Galicia. Decreto 79/2010, do 20 de maio, para o plurilingüismo no ensino non universitario de Galicia. Santiago de Compostela. 2010.

Xunta de Galicia. Estatuto de Autonomía de Galicia. Santiago de Compostela. 1981.

Xunta de Galicia. Lei 2/2009, do 23 de xuño, de modificación do texto refundido da Lei da función pública de Galicia, aprobado polo Decreto lexislativo 1/2008, do 13 de marzo. Santiago de Compostela. 2008. 